\title{
Advantages of Hybrid Corn Seed Production Compared to Corn Grain
}

\author{
Bahtiar*, B Zanuddin, M Azrai \\ Cereals Research Institute, Ministry of Agriculture, Indonesia. \\ *Corresponding author's e-mail: bahtiarhusain31121957@gmail.com
}

How to Cite: Bahtiar., Zanuddin B., and Azrai, M. (2020). Advantages of Hybrid Corn Seed Production Compared to Corn Grain. Int. J. Agr. Syst. 8(1): 44-56

\begin{abstract}
Corn seed breeders are indispensable in the supply of superior hybrid corn seeds. Its ability to produce seeds is evaluated for their superiority compared to the production of corn grain yield. A study was conducted in Jatirogo District, Tuban Regency, East Java province in July to December 2019. Involving farmers cooperator implementing hybrid corn seed production in the area of 96 ha and non cooperator farmers who produce the corn grain yield in the same location. We observed the variables: cost of production, yield and farmers income. Data and information were analyzed by Benefit Cost Ratio (B/C) and Marginal Benefit Cost Ratio (MBCR). The results showed that farmers who produced hybrid corn seeds of Nasa-29 variety (cooperators) were able to produce 4.6 t/ha of wet cobs with an income of IDR. 19,470,000/ha, while farmers who produced grain corn of 7.9 t/ha with an income of IDR. 15,943,000/ha. MBCR analysis showed that, the switching is able to added the farmer income $R p .4,100$ for every use cost Rp.1,000 as long as the seed procurement policy remains unchanged and related institutions continue to provide support.
\end{abstract}

Copyright $\odot 2020$ IJAS. All rights reserved.

Keywords:

Hybrid maize; seed grower technology; farm transition; farm income

\section{Introduction}

National maize needs continue to increase from year to year with various designations, but dominant to meet the demand for the animal feed industry (Hermanto et al., 2015). In 2018 the national production will only reach 30 million tons and it is expected that in 2024 it will reach 38 million tons (Anonymous, 2019). To achieve the government implement various programs, among others: the expanded program of planting areas of new and intercropping, empowerment of the 760 growers, maize production improvement program in the area of 2 million hectares (Irianto, 2019).

Two roles that farmers can play in supporting the program are; as a corn farmer who produces corn grain and as a seed producer who produces quality seeds. The two fields of farming can be the choice of farmers to get adequate income, because hybrid corn cultivation can provide adequate income (Khan et al., 2014; Bahtiar \& M. Azrai, 2018). The cultivation technology of corn farming to produce corn grain has been 
familiar by farmers, but the technology of hybrid corn seed production still requires guidance and assistance to be able to become a sustainable producer.

Seed quality is the main and first factor that determines the success of farming (Setimela et al., 2004; Saenong et al., 2007; Tahir et al., 2008). The mechanism of procuring corn seeds in Indonesia is still considered to be through a long bureaucracy, making it possible for problems to occur at every level and ultimately harming farmers as users of the seeds. The fact shows that farmers still often want certain varieties, but those available in other varieties (Setimel, 2006), availability is not timely, so farmers are late planting or using seeds that are not of quality (Bahtiar et al., 2010). These problems can be minimized by producing seeds in an integrated manner within the corn development area itself (Tipp and Mennsah-Bonsu, 2013; Takdir, 2018).

Seed production technology is available, and proven to be done well by the farmers (Azrai and Bahtiar, 2015). The results of coaching farmer groups on the activities of independent villages of corn seeds in different provinces shows that, farmers can produce hybrid corn seed quality (Hippi et al., 2015), but not all of the farmers groups that sustaining because of marketing problems. Farmers in the seed independent village area are also registered as recipients of subsidized seeds, so that the growers face selling problem (Bustaman, 2016). Empowering farmer groups have a lot of challenges, because the farmer has many weakness in developing farming (Mulatsih and A. Fatony, 2006). Growers having weak both in terms of the application of technology, and in accessing the market (Akhter et al., 2020) and it weakens by the presence of large companies that dominate the market (Robert T. and Ch. Ragasa, 2015 ; Monyo et al., 2004 ), Therefore, an integrated program is needed in which : (1) there is an activity to improve education and skills in the process of transfer of cultivation and yield processing technology (Boehringer, 2002; Nchinda et al. 2010), (2) there is development of activity management business, resulting in cost efficiency (Mkhari et al., 2005), and (3) there are activities that strengthen the bargaining position of farmers in marketing the product (Nambiro et al., 2002).

Realizing that challenges, in 2019 a partnership was implemented in the production of hybrid corn seeds based on farmer corporations in a corn production central area on the island of Java. Farmer groups as seed grower are assisted by researchers with national company in applying the technology, supervised by the seed supervisor and certification center (BPSB) implementation in the field until the seed legitimate, and the seeds produced are absorbed by the Department of Agriculture to be used by farmers in target areas. It is recognized that the partnership program production of corn-based corporation, can only continue if the program should be increased farmers' income (Vanitha P, and Karthigaipriya T. 2017). Therefore, it is necessary to know the difference of the profits obtained by growers compared with the profits obtained by farmers. That is as an effort to empowering the grower produce the seeds needed by farmers in and outside the region.

\section{Materials and Methods}

\subsection{Time and Site Research}

The research was done for six months, from July to December 2019, carried out by an integrated team of government officials and seed producers to foster and assist implementing farmer groups in the field. The research was conducted in the Jatirogo District Tuban, East Java, with consideration of : (1) Jatirogo District once was the site 
of production of the hybrids corn from the private seed producers: BISI, Pioneer, and Syngenta, (2) the farmers had experienced produce hybrid corn seed, (3) the area including within the area of the development of maize (Anonymous, 2016), and (4) the farmer is already become the partner of PPL in various activities of demonstration plots and are willing to be cooperative and follow the SOP production of hybrid corn seed is recommended (Mulila et al., 2006). There are two farms evaluated, namely; national hybrid corn seed production farms by farmer groups (cooperators) and corn grain production (non-cooperator). The technology component of maize crop production on activities is adjusted to the habits of the existing farmers, while the technology component applied to the production of hybrid corn seed production in the Nasa-29 variety in the 96 ha area is detailed as in table 1.

Table 1. Operational standards for implementing hybrid corn seed production , 2019

\begin{tabular}{|c|c|}
\hline Description & Recomendation \\
\hline Land preparation & Isolated, non-pest-endemic, friable and weed-free areas \\
\hline Seed treatment & $\begin{array}{l}\text { The seeds used were strain } 10261212 \text { as male parent of } 5 \mathrm{~kg} / \mathrm{ha} \text { and MAL- } \\
03 \text { as female parent of } 15 \mathrm{~kg} / \mathrm{ha} \text {. Treated with Saromil at a dose of } 3 \mathrm{gr} / \mathrm{kg} \\
\text { of seeds dissolved in } 10 \mathrm{cc} \text { of water, mixed until evenly distributed, } \\
\text { aerated before planting }\end{array}$ \\
\hline Planting & $\begin{array}{l}\text { Spacing of } 70 \mathrm{~cm} \times 20 \mathrm{~cm}, 1 \text { seed } / \text { hole, comparison of male rows with } \\
\text { female rows 1: } 4\end{array}$ \\
\hline Fertilization & $\begin{array}{l}\text { Fertilizing dose I: Urea } 100 \mathrm{~kg} / \mathrm{ha} \text {, Ponska } 350 \mathrm{~kg} / \mathrm{ha} \text {, applied } 7-10 \text { days } \\
\text { after planting (DAP), Fertilization II: } 200 \mathrm{~kg} \text { urea/ha given at } 25-35 \\
\text { DAP. Compost is used to cover the planting hole when planting }\end{array}$ \\
\hline Weeding & $\begin{array}{l}\text { 1. Herbicide Calaris } 1.5 \mathrm{ltr} / \mathrm{ha} \text { is sprayed when weeds are trapping } \\
\text { usually at } 10-15 \mathrm{DAP} \text { and an effort is made to keep the soil moist } \\
\text { 2. Manual with a hoe or other supporting if required }\end{array}$ \\
\hline Selection & $\begin{array}{l}\text { 1. At } 1-2 \text { weeks after planting (WAP) to uproot plants that grow } \\
\text { outside the row } \\
\text { 2. At } 4-5 \text { WAP to uproot plants that deviate leaves, stems and roots, } \\
\text { and plants that are sick, stunted } \\
\text { 3. At } 7-8 \text { WAP to uproot plants that deviate male flowers (panicle color } \\
\text { and shape) and female flowers (cob position and hair color) }\end{array}$ \\
\hline Pest Control & Based on farmers' habits and experiences. Prevention is preferred. \\
\hline Detasseling & $\begin{array}{l}\text { In the female row, male flowers are removed before blooming } \\
\text { pollinating (usually at the age of } 50-55 \text { DAP), while in the male row of } \\
\text { male flowers that deviate in different colors and shapes are also revoked }\end{array}$ \\
\hline Harvesting & $\begin{array}{l}\text { The male is first harvested and then the female. Harvest female rows } \\
\text { when they are ripe physiology marked by the formation of a blackish } \\
\text { brown color on the seeds (black layer) }\end{array}$ \\
\hline Processing & $\begin{array}{l}\text { the harvest is put into a bag of onions and immediately transported to the } \\
\text { dryer. }\end{array}$ \\
\hline
\end{tabular}

\subsection{Sampling}

Research activities involving many farmers can be classified into several groups to answer the objectives (Franzel et al., 2001). Regarding to this statement, respondents (farmers) were divided into two groups in each village, namely: (1) farmers carrying out the production of national hybrid corn seeds, deliberately selected of 50 farmers spread over 7 villages within the Jatirogo sub-district area. (2) farmers who plant corn graind (non-cooperators) are selected of 50 
farmers based on dominant varieties planted by farmers around location (Table 2 ).

Table 2. Distribution of farmers in Jatirogo District , 2019

\begin{tabular}{|c|c|c|}
\hline \multirow{2}{*}{ Location (village) } & \multicolumn{2}{|c|}{ Farmers (people) *) } \\
\hline & Cooperator & Non-Cooperator \\
\hline Besowo & 8 & 7 \\
\hline Kebonharjo & 10 & 9 \\
\hline Paseyan & 8 & 8 \\
\hline Sekaran & 9 & 9 \\
\hline Wangi & 5 & 5 \\
\hline Demit & 6 & 6 \\
\hline Kedung Makam & 4 & 6 \\
\hline Amount & 50 & 50 \\
\hline
\end{tabular}

*) Cooperator : Farmers who carry out the corn seed production

Non cooperator : farmers who plant corn grain

\subsection{Data Collection}

The data needed in analyzing the socioeconomic farming include: planting area, availability of input production and its prices, labor and wage rates of farm laborers, and results obtained and yield prices, as well as related social factors (Nagam, SN, 2007). Correspondingly, the data required is primary data from respondents and secondary data from relevant agencies. For primary data in the form of: (1). The use of total means of production, the availability and the price at the farm level, especially that are not available in the package; (2). The use of labor in the production of hybrid corn seed farming ranging from land preparation to harvest, the level of wages applicable in farming, the results of the cob obtained. The data was collected by the method of observation and interviews using a questioner.

\subsection{Data Analysis}

Two methods used in the analysis; Benefit Cost Ratio (B/C) to determine the contribution of unit cost to income (Kasim, 2004), and Marginal Benefit Cost Ratio (MBCR) to determine the feasibility of transition technology (Malian, AH, 1989). The two methods are formulated as follows:

1. Benefit Cost Ratio Analysis

$$
\mathrm{B} / \mathrm{C}=\frac{(Y . P y)-T C}{T C}
$$

$\mathrm{B} / \mathrm{C}>1$ is profitable

$\mathrm{B} / \mathrm{C}<1$ is unprofitable

2. Marginal Benefit Cost Ratio

$$
\text { MBCR }=\frac{(\text { Y. Py A })-(\text { Y. Py B })}{(\text { TC A }- \text { TC B })}
$$




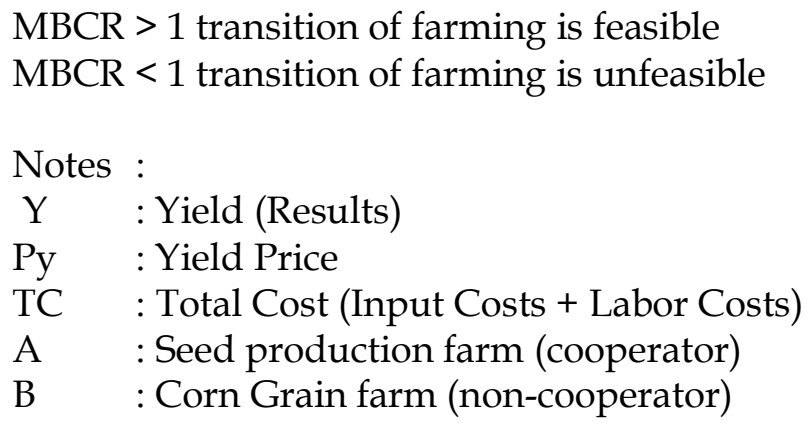

\section{Results and Discussion}

The good planting season for maize in area is April-August, while the growing season for corn seed production cancel to July-December, due to various reasons: readiness of team, selecting of acuration location proces to esuran isolated locations and farmers willing to following. The performance of the team in the research was considered quite good. They were able to carry out its duties and authorities, so it can produce high quality seed.

Guidance for breeder farmers (cooperators) begins with socialization and training on Standard Operating Procedures (SOP) for hybrid corn seed production with a team: (1) Director of general for food crops explaining the objectives and mechanism of research, (2) Researchers train seed production technology and explain characters of variety with to be produced (Nasa-29), (3) Supervisors from BPSB convey the way of supervision starting from the field to get seed certificates (labels), (4) Head of Food Crop Production Division, Tuban District Agriculture Office conveying the benefits of research to farmers and expectations of the central and regional, (5) Director of PT. TWINN presented a model of field assistance to harvest, purchase price and handling procedures. The training material is used as a basis for coaching and observing the use of input production, labor and the results obtained by farmers, as well as the problems and challenges faced.

\subsection{Cost of Input Production}

The cost of input production used by cooperator farmers is higher than the costs of input production used by non-cooperator farmers. The differences lies in the use saromil for seed treatment (seed treatment), fungicides, and fuel oil. The expenditure for fuel oil in this study is IDR.356.000/ha. This is in accordance with farming carried out in Central Sulawesi which uses a cost of watering around IDR.444.453/ha (Ahmad, Z.et al.,(2015). The three that spending cost, does not occur on non-cooperator, because the time plantations in accordance with the planting season. It is different with cooperator farmers planting which is carried out in off season, facing drought and Fall Armyworm Pests, so farmers must use pump water to irrigated the planting area and use more insecticides/fungicides as the consequences of planting out of season (Kumar et al., 2011). Summase et al. (2019), reported that three factors were taken into account by farmers to develop their farming, namely: (1) market demand related to favorable prices, (2) efficient and effective use of fertilizer and pesticide, and (3) utilization of water resources for maintain the continuity of plant growth.

Another factor influencing the using input production more on the farmer cooperator, is seed planted still relatively strains that have adaptability lower compared with the varieties, so it requires more intensive maintenance especially when it happens Pest 
Army Worms so that farmers use more of insecticides and fungicides to control these pests (Table 3 ).

Table 3. Use of input production in research, Jatirogo District, 2019

\begin{tabular}{|c|c|c|c|c|c|c|}
\hline \multirow{2}{*}{$\begin{array}{l}\text { Input } \\
\text { production }\end{array}$} & \multicolumn{3}{|c|}{ Cooperators $(n=50)$} & \multicolumn{3}{|c|}{ Non-Cooperator $(n=50)$} \\
\hline & Amount 1 & $\begin{array}{c}\text { Price } \\
\text { (IDR/unit) }\end{array}$ & $\begin{array}{c}\text { Value } \\
(\text { IDR,000) }\end{array}$ & Amount ${ }^{2}$ & $\begin{array}{c}\text { Price } \\
\text { (IDR/unit) }\end{array}$ & $\begin{array}{c}\text { Value } \\
(\mathrm{IDR}, 000)\end{array}$ \\
\hline Seed & $20 \mathrm{~kg}$ & 90,000 & 1,800 & $20 \mathrm{~kg}$ & 87,500 & 1,750 \\
\hline Saromil & $60 \mathrm{~g}$ & 2,000 & 120 & - & - & - \\
\hline Urea & $300 \mathrm{~kg}$ & 1,100 & 330 & $475 \mathrm{~kg}$ & 1,100 & 522 \\
\hline Ponska & $350 \mathrm{~kg}$ & 1,300 & 455 & $200 \mathrm{~kg}$ & 1,300 & 260 \\
\hline Organic Matter & $501 \mathrm{~kg}$ & 250 & 125 & $300 \mathrm{~kg}$ & 250 & 75 \\
\hline Liquid fertilizer & $2,4 \mathrm{btl}$ & 20,000 & 48 & $3.2 \mathrm{btl}$ & 20,000 & 64 \\
\hline Insecticide & $7.8 \mathrm{btl}$ & 55,000 & 429 & $5.8 \mathrm{btl}$ & 55,000 & 319 \\
\hline Fungicide & $2.2 \mathrm{btl}$ & 75,000 & 165 & - & - & - \\
\hline Herbicide & $3.6 \mathrm{btl}$ & 150,000 & 540 & $5.4 \mathrm{btl}$ & 85,000 & 459 \\
\hline Fuel Oil & 50.8 ltr & 7,000 & 356 & - & - & - \\
\hline Amount & & & 4.368 & & & 3,449 \\
\hline
\end{tabular}

1) Package of technology in maize seed production

2) Existing technology in maize crop production (farmers' habits).

The seeds used by cooperator farmers are strain 10262 as males $5 \mathrm{~kg} / \mathrm{ha}$ and MAL-03 as females $15 \mathrm{~kg} / \mathrm{ha}$ must be given a treatmen with Saromil and proporsional fertilizer to provide maximum results. Therefore, the amount of NPK fertilizer is greater. According to Mkhari et al. (2005), the costs that must be prepared in seed production farming are always more because the price of seeds is more expensive, so farmers tend to maximize the use of inputs to get more seed yields. In contrast to farmers who produce grain yield are more likely to use more urea because of its direct effect seen in vegetative growth and also the price is cheaper than NPK fertilizer.

\subsection{Cost of Labor Production}

Farming activities require a lot of labor, especially in activities of land preparation and plant maintenance. The need is dependent on many factors, namely: the difficulty level of the land, land size, availability of water, pest attack. The use of labor in seed production farming (cooperator) is higher than the use of labor incorn graind farming (non-cooperator), because there are additional activities that require a lot of energy in seed production farming, namely planters arranged so that the distance is spaced to provide space for each plant to obtain nutrients (Bee KhimChim et al., 2014; Widdicombe and Thelen, 2002). According to Doerge et al., (2002) that crop yields can be increased up to $0.25 \mathrm{t} /$ ha for each increase of $2.54 \mathrm{~cm}$ in the standard deviation of planting spacing. Other activities that increase labor are selection to remove deviant plants and extraction of male flowers to maintain the purity of the seeds produced (Table 4$)$. 
Table 4 . The use of labor in research in Jatirogo District , 2019

\begin{tabular}{|c|c|c|c|c|}
\hline \multirow[b]{2}{*}{ Activities } & \multicolumn{2}{|c|}{ Cooperators $(n=50)$} & \multicolumn{2}{|c|}{ Non-cooperator $(\mathrm{n}=50)$} \\
\hline & $\begin{array}{l}\text { Amount } \\
\text { (WD) }\end{array}$ & $\begin{array}{c}\text { Value }{ }^{1)} \\
\text { (IDR.1,000/ha) }\end{array}$ & Amount (WD) & $\begin{array}{c}\text { Value 1) } \\
\text { (IDR.1,000/ha) }\end{array}$ \\
\hline Land preparation & 15.8 & 1,264 & 15.2 & 1,216 \\
\hline Planting & 4.2 & 336 & 3.8 & 304 \\
\hline Weeding I & 1.8 & 144 & 1.6 & 128 \\
\hline Fertilization I & 3,2 & 256 & 2,4 & 192 \\
\hline Weeding II & 1.6 & 128 & 1.6 & 128 \\
\hline Selection I & 1.8 & 144 & & - \\
\hline Fertilization II & 2.8 & 224 & 2.6 & 208 \\
\hline Selection II & 1.6 & 128 & & - \\
\hline Detaseling & 5.2 & 416 & & - \\
\hline Irrigation & 2.8 & 224 & 3,2 & 256 \\
\hline Harvest & 4.2 & 336 & 3.8 & 304 \\
\hline Processing & 0 & - & 8.2 & 656 \\
\hline Amount & 45.0 & 3,600 & $\overline{42}$ & 3,392 \\
\hline
\end{tabular}

1)Wages of farm laborers IDR.80,000/Working Day (WD)

The selection of the plants require extra labor in farming for at least three times the selection are: (1) at the time the plant was 1-2 WD, plants that grow beyond the line must be removed, (2) at the time the plant was $4-5 \mathrm{WD}$, plants deviate stems, leaves and roots revoked, (3) at the 7-8 WD, male flowers and female flowers that deviate revoked to maintain the purity of the seeds produced, but the additional work is not a problem for farmers.

In pre-production, planting and fertilizing activities that using a lot of energy, but that is not a problem because mutual cooperation are still very strong (Umar et al., 2014; Awotide and Tontsa, 2011). Mutual assistance between farmers are still going on , so that labor costs in real terms only in the form of the cost of consumption, although the number is sometimes higher (Belean et al., 2014). It is very important to be preserved to strengthen the togetherness and cohesiveness of farmer groups in carrying out farming activities (Syahyuti, 2007; Crame and CW. Jensen, 2001; Bustaman, 2014). According to Yunus A., et al., (2018),Social institutionalization is very important in preserving the farming system, including the adoption of new technology. Then in the post-harvest, harvesting and shelling activities that using the most energy. Counting the time used to process the results is in the range of 5-10 days (an average of 8.2 days) from the start of drying the cobs, shelling, and drying seeds. This is influenced by weather conditions during harvest.

Otherwise with cooperator farmers, they are free from processing costs, because the yield in the form of wet cobs are bought by the Seed Company at harvest time. The cobs is selected and immediately packed, weighed, and paid according to the agreed price (IDR.6,000/kg). This has become one of the stimulant for farmers, because it is no longer preoccupied with transportation and processing of produce, and the price is more expensive than the price of corn grain. According to Arsyad (2019), two things have a positive effect on increasing the enthusiasm of farmers in doing business are product price certainty and ease of obtaining information from technology sources. 


\subsection{Income Analysis}

Based on an economic analysis, corn hybrid seed production farming (cooperator) and corn grain production farming (non cooperator) are profiable which shown by B/C greater 1 (Simatupang, 2003). But cooperator farmers receive a greater income than the income received by non-cooperator farmers. The difference is quite large at IDR 3,527,000 (Table 5). This income factor is the strongest to attract farmers to switch from farming to produce corn grain to produce hybrid corn seeds. In addition, the price is also very decisive certainty (Sapkota et al., 2017). Prices seed is not affected by fluctuations market prices, while the price of corn at the farm level is still fluctuate between IDR.2.700/ kg to IDR.3.500/kg. Farmers who harvest early can still sell at high prices, but farmers who have harvest the late have decreased prices, which means the law of supply and demand still applies which at the farm level is very difficult to control because the nature of seasonal crops is relatively concurrent harvesting, resulting in overflow production at the height of the harvest. The seeds produced as must as possible to be distributed and also provided assistance to target farmers in the region as an effort to support the sustainability of hybrid corn seed production (Westengen et al., 2014).

Table 5. Income analysis in research in Jatirogo District, 2019

\begin{tabular}{lcc}
\hline \multirow{2}{*}{ Description } & \multicolumn{2}{c}{ Respondents } \\
\cline { 2 - 3 } & Coorporator $(\mathrm{n}=50)$ & Non-Cooperator $(\mathrm{n}=50)$ \\
\hline Planting area range (ha) & $0.34-0.95$ & $0.32-1.32$ \\
Production Range (t/ha) & $3,735-5,215$ & $5,143-8,321$ \\
Average production (kg/ha) & 4,573 & 7,350 \\
Revenue (IDR,000/ha) *) & 27,438 & 22,785 \\
Input Costs (IDR,000 / ha) & 4,368 & 3,449 \\
Labor Costs (IDR,000 / ha) & 3,600 & 3,392 \\
Total cost (IDR,000 / ha) & 7.968 & 6,841 \\
Income (IDR,000 / ha) & 19,470 & 15,943 \\
B/C ratio value & 2,4 & 2,3 \\
\hline
\end{tabular}

*) rice of corn seed = IDR. 6,000/kg, price of corn grain = IDR.2,700-3,500/kg

The success of the hybrid maize farm is similar to the results of a new variety demonstration plot in North Luwu Regency which showed that the use of cost around 7.5 to 8.5 million per hectare can provide an income of 20 to 21 million per hectare (Bahtiar \& Azrai, (2019). MBCR analysis shows that even though the production costs required to produce hybrid corn seeds are much greater than the production costs to produce corn graind, which is the difference of one rupiah per hectare, it is still far more profitable, because the difference in revenue is far greater, namely four million rupiah per hectare (Table 6). This means that additional comparisons margin acceptance by the margin costs reaching 4.1 times that if the non-cooperator farmer modeled on the cooperator farmer, they would get an additional income of IDR4,100 for each use of the production cost of IDR 1,000. Syuryawati and Faesal (2018), reported that the transition from farmers' cultivation methods to modern methods of farming can provide additional benefits of IDR.6,000 to IDR 8,000 for each use of Rp. 1,000. These advantages were considered very feasible for farmers in rural areas (Adnyana and Kariyasa, 2006). The advantage is still likely to be increased by planting on time. The results of breeding corn seeds carried out on time avoid the 
drought and high pest attacks and can produce seed candidates as much as 5 to $6 \mathrm{t} / \mathrm{ha}$ wet cobs (Bahtiar and Suriay, 2018; Irma et al., 2019). According to Brick and Visser, (2015) the courage of farmers to face risk is the main driving factor in adopting new technologies.

Table 6. MBC analysis of research in Jatirogo District, 2019

\begin{tabular}{lrrr}
\hline \multirow{2}{*}{ Description } & \multicolumn{2}{c}{ Respondents } & \\
\cline { 2 - 3 } & $\begin{array}{c}\text { Coorporator } \\
(\mathrm{n}=50)\end{array}$ & $\begin{array}{c}\text { Non-Cooperator (n } \\
=50)\end{array}$ & Difference \\
\hline Revenue (IDR,000 / ha) & 27,438 & 22,785 & 4,653 \\
Total production cost (IDR,000 / ha) & 7,968 & 6,841 & 1,127 \\
MBCR & & & 4,1 \\
\hline
\end{tabular}

The advantages of cooperator farmer in producing hybrid corn seeds are expected to be: (1) a solution for farmers who have narrow land because additional inputs are lower than outputs and can increase farmer's income (Taufik and M.Thamrin, 2009); (2) an encourage for the emergence of new producer of hybrid corn seeds in production centers to meet the growing need for quality seeds, because the number of corn farmers and planting area of corn continues to increase (Hermanto et al., 2015; Irianto, 2019); (3) The government's reference to replicate the seeds production model based on farmer cooperatives at maize production centers in Indonesia.

\section{Conclusion}

The national hybrid corn seed production farm of Nasa-29 variety is more economically advantageous than the corn grain farm. The difference in profit reaches three million rupiah per hectare, so it is very possible for farmers to switch from corn grain farming to seed production farming. MBCR analysis showed, that the switching is able to added the farmer income Rp.4,100 for every use cost Rp.1,000 as long as the seed procurement policy remains unchanged and related institutions continue to provide support.

\section{References}

Adnyana, M.O. \& I.K. Kariyasa. (2006). Dampak dan persepsi petani terhadap penerapan sistem pengelolaan tanaman terpadu padi sawah. Jurnal Penelitian Pertanian Tanaman Pangan, 25(1)21-29.

Ahmad, Z. A. Purwanto, Hadayani, \&A. Muis, (2015). Analisis Produksi dan Pendapatan Usahatani Jagung Hibrida Di Desa Modo Kecamatan Bukal Kabupaten Buol. Journal Agroland. 22(3): 205 - 215.

Anonymous. (2016). Surat Keputusan Menteri Pertanian Republik Indonesia No.830/Kpts/RC.040/12/2016 tentang Lokasi Pengembangan Kawasan Pertanian Nasional. Kementerian Pertanian, Jakarta, 2016.

Anonymous. (2019). Revisi Rencana Strategis (RENSTRA) Dirjen Tanaman Pangan 2015-2019. Direktorat Jenderal Tanaman Pangan, Kementerian Pertanian Republik Indonesia. 
Akhter Ali, A.R.B. Issa, and D.B. Rahut. (2020). Adoption and Impact of the Maize Hybrid on the Livelihood of the Maize Growers: Some Policy Insights from Pakistan. pp:1-8

Arsyad. M (2019). Prices of Agricultural Products and Poverty: How Strongly are the Two Linked?. International Journal of Agriculture System, 7(12):148-153

Awotide and Tontsa HM. (2011). Small-scale maize seed production in west and central Africa: profitability, constraints and options. ICBE-RF Research Report No. 21(11); 2011.

Azrai, M. \& Bahtiar. (2015). Teknologi produksi benih hibrida dan OPV. Makalah Disampaikan pada Acara Pelatihan Pendampingan Teknologi GP-PTT dan Kawasan Mandiri Benih Jagung. Balai Pengkajian Teknologi Pertanian Sulawesi Tenggara. Kendari, 3 Maret 2015.

Bahtiar \& Suriany. (2018). Analisa pendapatan usahatani produksi benih jagung hibrida nasional: Studi Kasus: Desa Mandiri Benih Jagung di Sulawesi Selatan. Bulletin Inovasi Pertanian Spesifik Lokasi. 4(1): 33-42

Bahtiar \& M. Azrai. (2019). Respon Pengguna Terhadap Potensi Hasil Tiga Varietas Jagung Unggul Baru Badan Litbang Pertanian Di Luwu Utara, Sulawesi Selatan. Bulletin Tanaman Serealia. 3(1): 36-48.

Bahtiar, W. Rembang, \& A. Tenrirawe. (2010). Prospek produksi benih jagung komposit di provinsi Sulawesi Utara. Prosiding Pekan Serealia Nasional, pp:574580

Belean, W. Hariadi, S.Wastutiningsih, S.Peni. (2014). Pengaruh kepemimpinan transpormasi terhadap kemandirian gapoktan. Jurnasl Sosial Ekonomi Pertanian. 7(2): 76-83

Bee Khim Chim, Peter Omara, Natasha Macnack, Jeremiah Mullock, Sulochana Dhital, and William Raun. (2014). Effect of Seed Distribution and Population on Maize (Zea mays L.) Grain Yield. (2):8

Boehringer. (2002). Facilitating the wider use of agroforestry in southern Africa. In Franzel, S., Cooper P, Denning GL. and Eade D (eds) Development and Agroforestry: Scaling Up the Impacts of Research. ICRAF/Oxfarm, UK. pp: 434448

Brick, K.; Visser, M. (2015). Risk preferences, technology adoption and insurance uptake: A framed experiment. J. Econ. Behav. Organ. 118: 383-396.

Bustaman, Sy. (2014). Penguatan kelembagaan gapoktan PUAP dalam penerapan teknologi spesifik lokasi. Jurnal Penelitian dan Pengembangan Pertanian. 33(1): $35-46$

Bustaman, Sy. (2016). Progres pelaksanaan kegiatan desa mandiri benih lingkup Balai Pengkajian dan Pengembangan Teknologi Pertanian. Makalah disampaikan pada Rapat Kerja Evaluasi dan Monitoring Kegiatan Mandiri benih Padi, Jagung dan Kedelai. Pusat Penelitian dan Pengembangan Tanaman Pangan, Bogor, 2016.

Crame, G.L. and C.W. Jensen. (2001). Agricultural ekonomics and agribusiness. 8 th Edition. Published by John Wiley \& Sons, Inc. Canada.

Doerge, T. Hall, and D. Gardner. (2002). New research confirms benefits of improved plant spacing in corn. Crop Insights, 12(2); 1-11 
Elizabeth Nambiro, Hugo De Groote, and Willis Oluoch K'osura. (2002). Market Structure And Conduct Of The Hybrid Maize Seed Industry, A Case Study Of The Trans Nzoia District In Western Kenya. In Friesen D.K. and A. F. E. Palmer (eds.). Integrated Approaches to Higher Maize Productivity in the New Millenium. Proceedings of the 7th Eastern and Southern Africa Regional Maize Conference, Nairobi, Kenya, 11 - 15 February 2002. Mexico, D. F.: CIMMYT, pp. 474-479

Franzel SR, Coe R, Cooper F, Place F and Scherr SJ. (2001). Assessing the adoption potential of agroforestry practices in Sub-Saharan Africa. Agriculture System: 69:37-62.

Hermanto,D. H. Azahari, M. Rachmat, Ny. Ilham, I.K. Kariyasa, Supriyati, A. Setiyanto, R.D. Yofa, E.S. Yusuf. (2015). Outlook Komoditas Pangan Strategis Tahun 2015-2019. Laporan Analisis Kebijakan Tahun 2015. Pusat Sosial Ekonomi dan Kebijakan Pertanian. Badan Penelitian dan Pengembangan Pertanian. Jakarta. pp:1-148

Hipi, A., Herawati, \& M.S. Mochtar. (2015). Model penyediaan benih untukpemenuhan kebutuhan wilayahnyamelalui peningkatan kemampuan calon penangkar padi dan jagung di Nusa Tenggara Barat. Makalah disampaikan dalam Workshop Balai Besar Pengembangan dan Pengkajian Teknologi Pertanian, Bogor, 10-13 November 2015.

Irianto G.S. (2019). Program Kegiatan Tanaman Pangan Tahun 2020. Makalah disampaikan pada acara Musrembangtannas, Hotel Botani Bogor, 18 Juni 2019.

Irma, A., Abid, \& A. Baso. (2019). Produksi benih jagung hibrida varietas Nasa-29 di kecamatan Dolo Barat. Laporan Kegiatan Desa Mandiri Benih jagung. Balai Pengkajian Teknologi Pertanian Sulawesi Tengah. Unpublish.

Kasim, K. (2004). Petunjuk Menghitung Keuntungan dan Pendapatan Usahatani. Universitas Lambung Mangkurat. Banjarbaru.

Khan, S. Khan, S. Fahad et al. (2014). Effect of different levels of nitrogen and phosphorus on the phenology and yield of Maize Varieties, American Journal of Plant Sciences, 5(17): 2582-2590

Kumar, P. K. Aggarwal, S. Rani, S. Jain, R. Saxena, and N. Chauhan. (2011). Impact of climate change on crop productivity in Western Ghats, coastal and northeastern regions of India, Current Science, 101(3): 332-341

Malian, A.H. (1989). Penggunaan anggaran pendapatan dan biaya usahatani untuk pengujian kemampuan ekonomi teknologi pola tanam. Dalam A.H. Malian, A. Djauhari, dan M.G. Van Der Veen (Peny). Training Course Economic Analysis in Farming Systems Research. Nusa Tenggara Agricultural Support Porject. pp: $165-178$

Mkhari, M.R. Matlebjane, K.P. Dlomu, N.D. Mudau and K.Mashingaidze. (2005). Cace study of a community-based seed production scheme in two district of the Limpopo Province, Shout Africa. In Peter S. Setime and Petr Kosina (edt. 2006). Strategies for Strengthening and Scaling Up Community-Based Seed Production. Mexico. pp: $14-25$

Monyo, E.S., Mgonja, Rohrbach. (2004). New Partnership to strengthen seed system in Southern Africa: Inoovative Community/Commercial Seed Supply Models. 
Mulatsih, S. \& A. Fatony. (2006). Peran delivering subsistem dalam sistem inovasi pertanian: Difusi Varietas Unggul Padi. Pusat Penelitian Perkembangan Ilmu Pengetahuan dan Teknologi. Lembaga Ilmu Pengetahuan Indonesia (LIPI). LIPI Press. Jakarta:

Mulila-Mitti, C. Jucquet de Haveskercke, G.Kabwe and R. Katanga. (2006). Scaling Up strategies in reference to Agroforestry. In Peter S. Setime and Petr Kosina (edt. 2006). Strategies for Strengthening and Scaling Up Community-Based Seed Production. Mexico. pp: 19-25

Nagam, S.N. (2007). Designing farmer-participatory varietal selection. Masood Ali, Sanjeev Gupta P.S. Basu dan Naimuddin (eds). Legumes for Ecological Sustainability. Indian Society of Pulses Research and Development. Kampur. pp:519-528

Nchinda VP, Ambe TE, Holvoet N, Leke W, Che MA, Nkwate SP, Ngassam SB, Njualem DK.(2010). Factors influencing the adoption intensity of improved yam (Dioscorea spp.) seed technology in the western highlands and high guinea savannah zones of Cameroon. J Appl Biosci. 36:2389-402

Robert Tripp and Chatene Ragasa. (2015). Hybrid maize seed supply in Chana. Strategy Support Program. International Food Policy Research Institute (IFPRI). pp: 1-27.

Saenong, S., M.Azrai. R. Arief, dan Rahmawati. (2007). Pengelolaan benih jagung. Buku jagung.Teknik Produksi dan Pengembangan. Puslitbang Tanaman Pangan. Badan Litbang Pertanian. pp: 145-176.

Sapkota, M., Joshi, Kattel. (2017). Determinants of maize seed income and adoption of foundation seed production: evidence from Palpa District of Nepal. Agric $\mathcal{E}$ Food Secur. 6, 41. pp:1-10

Setimela P.S., Monyo, E.S. and Banziger M.(eds). (2004). Successful Cummunity-Based Seed Production Strategies. CIMMYT Mexico.

Setimela, P.S. (2006). Analysis of Community Based Maize Seed Production and Supply Schemes in Sub-Saharan Africa. In Peter S. Setime and Petr Kosina (edt. 2006). Strategies for Strengthening and Scaling Up Community-Based Seed Production. Mexico: pp: 8-13

Simatupang, P. (2003). Daya saing dan efisiensi usahatani jagung hibrida di Indonesia. Dalam: Kasryno, F., E. Pasandaran, dan A.M. Fagi (Peny). Ekonomi Jagung Indonesia. Bogor: pp:165-177

Soekartawi. (1989). Prinsip dasar ekonomi pertanian. Teori dan Aplikasi. Penerbit C.V. Rajawali Pers, Jakarta.

Summase.I, M. Saleh S. Ali, D.Salman, D. Rukmana. (2019). Influence of Government Policy on Highland Agriculture Development in Enrekang Regency, South Sulawesi, Indonesia. International Journal of Agriculture System. 7(12):100-105

Syahyuti. (2007). Strategi dan Tantangan dalam Pengembangan Gabungan Kelompok Tani (GAPOKTAN) sebagai Kelembagaan Ekonomi di Pedesaan. Pusat Analisis Sosial Ekonomi dan Kebijakan Pertanian. Bogor. 
Syuryawati \& Faesal. 2016. Kelayakan finansial penerapan teknologi budidaya jagung pada lahan sawah tadah hujan. Jurnal Penelitian Pertanian Tanaman Pangan 35(1): 71-80.

Tahir, A. Tanveer, A. Ali, M. Abbas, and A. Wasaya. (2008). Comparative yield performance of maize and Zea mays, different maize (Zea mays L.) hybrids under local conditions of Faisalabad-Pakistan, Pakistan Journal of Life and Social Sciences, (6):118-120

Takdir, M. (2018). Sasaran dan realisasi pelaksanaan kegiatan desa mandiri benih. Makalah disampaikan pada Rapat Kordinasi Sekolah Lapangan Kedaulatan Pangan Mendukung Swasembada Pangan Terintegrasi Mandiri Benih, Bogor, 02 Maret 2018.

Taufik \& M. Thamrin. (2009). Analisis input output pemupukan beberapa varietas jagung di lahan kering. Penelitian Pertanian Tanaman Pangan. 28(2): 78-82.

Tipp and Mennsah-Bonsu. (2013). Ghana's Commercial Seed Sector. New Incentives or Continued Complacency? GSSP Working Paper 32 Accra: IFPRI\}. pp:1-20

Umar S, Sanni SA, Usman IS, Shuaibu H.2014. Community maize seed production as an income generating activity for poverty alleviation in selected communities of Zamfara state, Nigeria. In: Proceeding of the conference of Dryland, pp: 164-168

Vanitha P, and Karthigaipriya T. (2017). Infrastructure Management In Rural Development - A Study In Nagamalai Pudukottai Of Madurai District. International Journal of Innovative Research and Advanced Studies (IJIRAS). 4(3): $1-5$

Westengen, K. H. Ring, P. R. Berg, and A. K. Brysting. (2014). Modern maize varieties going local in the semi-arid zone in Tanzania. BMC Evolutionary Biology, 1(14):

Widdicombe and K. D. Thelen. (2002). Row width and plant density effects on corn grain production in the Northern Corn Belt. Agronomy Journal, 94(5): 1020-1023

Yunus A., Darmawan Salman, Eymal B. Demmallino, Ni Made Viantika, (2018). Sociotechnical Change and Institutional Adjustment in Paddy Rice Farming During Post Green Revolution in Indonesia. International Journal of Agriculture System. 4(2): 218-227. 